\title{
Sugar source modulates exopolysaccharide biosynthesis in Bifidobacterium longum subsp. longum CRC 002
}

Correspondence

Gisèle LaPointe

gisele.lapointe@fsaa.ulaval.ca

Received 13 August 2009

Revised 13 October 2009

Accepted 21 October 2009

\author{
Julie Audy, † Steve Labrie, Denis Roy and Gisèle LaPointe
}

Institute for Nutraceuticals and Functional Foods, Université Laval, 2440 Boul. Hochelaga, Québec, OC G1V OA6, Canada

The effect of four sugars (glucose, galactose, lactose and fructose) on exopolysaccharide (EPS) production by Bifidobacterium longum subsp. longum CRC 002 was evaluated. More EPS was produced when CRC 002 was grown on lactose in the absence of $\mathrm{pH}$ control, with a production of $1080 \pm 120 \mathrm{mg} \mathrm{EPS} \mathrm{I}^{-1}(P<0.01)$ after $24 \mathrm{~h}$ of incubation. For fructose, galactose and glucose, EPS production was similar, at $512 \pm 63,564 \pm 165$ and $616 \pm 93 \mathrm{mg} \mathrm{EPS} \mathrm{I}^{-1}$, respectively. The proposed repeating unit composition of the EPS is 2 galactose to 3 glucose. The effect of sugar and fermentation time on expression of genes involved in sugar nucleotide production (galK, galE1, galE2, galT1, ga/T2, galU, rmIA, rm/B1 and $r m / C D$ ) and the priming glycosyltransferase ( $w b / E)$ was quantified using real-time reverse transcription PCR. A significantly higher transcription level of wblE (9.29-fold) and the genes involved in the Leloir pathway (galK, 4.10-fold; galT1, 2.78-fold; and galE2, 4.95-fold) during exponential growth was associated with enhanced EPS production on lactose compared to glucose. However, galU expression, linking glucose metabolism with the Leloir pathway, was not correlated with EPS production on different sugars. Genes coding for dTDP-rhamnose biosynthesis were also differentially expressed depending on sugar source and growth phase, although rhamnose was not present in the composition of the EPS. This precursor may be used in cell wall polysaccharide biosynthesis. These results contribute to understanding the changes in gene expression when different sugar substrates are catabolized by $B$. longum subsp. longum CRC 002.

\section{INTRODUCTION}

Bifidobacteria are indigenous members of the anaerobic microbiota of the human colon, and can positively influence gastrointestinal health (Leahy et al., 2005; Picard et al., 2005). Functional foods containing specific strains of bifidobacteria are thus becoming more popular (Roy, 2005). The capacities of bifidobacterial strains to survive food-processing technologies and remain viable during product storage are important selection criteria (Grand et al., 2003; Masco et al., 2007; Roy, 2005; Stanton et al., 1998). Exopolysaccharide (EPS) production could contribute to cell protection and survival as well as having

†Present address: Institut Rosell-Lallemand, 6100, avenue Royalmount, Montréal, OC H4P 2R2, Canada.

Abbreviations: EPS, exopolysaccharide; pGTF, priming glycosyltransferase; Q-PCR, quantitative real-time PCR; Q-RT-PCR, quantitative realtime reverse transcription PCR.

The GenBank/EMBL/DDBJ accession numbers for sequences determined in this study are EU372989 to EU372994.

Three supplementary tables are available with the online version of this paper. beneficial effects on human health, although these ecological and health-related roles are not fully understood (Ruas-Madiedo \& de los Reyes-Gavilán, 2005; RuasMadiedo et al., 2006). As fermentable substrates, bifidobacterial EPSs could contribute to modulating gut microbial populations (Salazar et al., 2008). In Bifidobacterium animalis subsp. lactis, EPS production seems to be enhanced in the presence of bile (RuasMadiedo et al., 2009), as has been found for two pathogenic Vibrio species (Hsieh et al., 2003; Hung et al., 2006). Surface polysaccharides are well known as virulence and colonization factors of pathogenic bacteria, but molecules produced by commensal gut micro-organisms are gaining attention for their role in developing a normal immune system through communication with the mammalian host (reviewed by Mazmanian \& Kasper, 2006).

EPSs can form a capsule when associated with the cell surface or can be released as slime into the medium (De Vuyst \& Degeest, 1999). The production of molecules such as EPS by some bifidobacteria may also enhance the viscosity of fermented food products, contributing to their rheological properties. EPSs produced by bifidobacteria can thus be considered as natural additives, which are 
preferred by some consumers over stabilizers of plant or animal origin (Boels et al., 2001b).

Although our understanding of EPS production, structure, biosynthesis and gene molecular organization in Grampositive bacteria has advanced (De Vuyst \& Degeest, 1999; Degeest \& De Vuyst, 1999, 2000; Degeest et al., 2001; Laws \& Marshall, 2001; Looijesteijn et al., 1999), relatively little is known about EPS produced by bifidobacteria. Only $17 \%$ of lactobacilli and bifidobacterial strains isolated from human gastrointestinal microbiota showed EPS production by phenotypic methods (Ruas-Madiedo et al., 2007). Bifidobacterium longum strain YIT4028 has been reported to have cell wall polysaccharides consisting of rhamnogalactan (Nagaoka et al., 1995), while three out of four EPSs characterized from B. longum also contained rhamnose (Salazar et al., 2009). More recently, the EPS repeating unit from B. longum strain JBL05 was shown to be a heptasaccharide containing glucose, galactose and rhamnose (Kohno et al., 2009). However, no rhamnose was reported in the EPS produced by B. longum strains ATCC 15707 and BB-79 (Abbad Andaloussi et al., 1995; Roberts et al., 1995). Polymorphism in polymer composition among bifidobacterial EPSs indicates that most can be classified as heteropolysaccharides and that the EPSspecific gene organization differs between $B$. longum strains (Ruas-Madiedo et al., 2007). However, no EPS gene locus from bifidobacteria has yet been functionally demonstrated.

Sugar nucleotides, along with glycosyltransferases, are involved in heteropolysaccharide repeat unit formation (Boels et al., 2001b; De Vuyst et al., 2001; Jolly \& Stingele, 2001). Hence, precursor sugar availability or transcriptional regulation in the biosynthesis and conversion pathways may modulate EPS production by cells grown on diverse sugar sources (Boels et al., 2001a, b, 2003a; Welman et al., 2006). To date, the influence of the sugar source on sugar nucleotide biosynthesis and its effect on EPS production are still unknown in B. longum. In $B$. longum subsp. longum strain NCC2705, lactose was found to be consumed before glucose (Parche et al., 2006) and a higher biomass productivity on lactose compared to glucose has been noted for B. longum subsp. infantis ATCC 27920 (Roy et al., 1991). The hypothesis of the current study was that the rate of transcription in cells growing on lactose should be higher than the rate of transcription in cells growing on glucose, resulting in higher expression of genes involved in sugar nucleotide and EPS biosynthesis. Quantitative real-time reverse transcription PCR was used to track specific gene expression at different phases of growth of $B$. longum subsp. longum CRC 002 on four sugars.

\section{METHODS}

Micro-organisms and storage conditions. B. longum subsp. longum CRC 002 (our collection) was stored at $-80{ }^{\circ} \mathrm{C}$ in de ManRogosa-Sharpe (MRS) medium (EMD Biosciences) supplemented with $15 \% \quad(\mathrm{v} / \mathrm{v})$ glycerol and $0.05 \% \quad(\mathrm{w} / \mathrm{v}) \quad$ L-cysteine. $\mathrm{HCl}$ (Calbiochem). Escherichia coli strain TOP10 transformants were grown in Luria Broth supplemented with $100 \mu \mathrm{g}$ ampicillin $\mathrm{ml}^{-1}$, which was solidified when necessary with $1.5 \%$ Bacto agar (Difco).

EPS production and isolation. For monomer determination by gas-liquid chromatography (GLC), B. longum subsp. longum CRC 002 was grown at $37^{\circ} \mathrm{C}$ in modified Norris broth without human milk. This semi-defined medium (Norris et al., 1950; Poupard et al., 1973) minimizes possible polysaccharide contamination from culture broth components. Initially, bacteria were transferred from storage at $-80{ }^{\circ} \mathrm{C}$ to $10 \mathrm{ml}$ modified Norris broth and were subcultured twice for $16 \mathrm{~h}$ at $37{ }^{\circ} \mathrm{C}$ in an AnaeroJar device (Oxoid); anaerobiosis was generated with an Anaerogen sachet (Oxoid). A 1.61 stirred-tank bioreactor (New Brunswick Scientific) containing 1.251 modified Norris broth was inoculated at $2 \%(\mathrm{v} / \mathrm{v})$ and was used to produce EPS in a $16 \mathrm{~h}$ fermentation at $37^{\circ} \mathrm{C}, 125$ r.p.m. agitation, at a controlled $\mathrm{pH}$ of 6.0 by automatic addition of $4 \mathrm{M} \mathrm{NH} \mathrm{NH}_{4} \mathrm{OH}$ and under anaerobic conditions by continuously bubbling $\mathrm{CO}_{2}$ gas. The EPS was extracted following the method of Cerning et al. (1994) and further purified as previously described (Dabour \& LaPointe, 2005). Monosaccharide analysis was performed by GLC as described previously (Van Calsteren et al., 2002).

Growth kinetics in small-scale fermentations. B. longum subsp. longum CRC 002 was grown in no-sugar MRS-based broth (Institut Rosell-Lallemand, Montreal, QC, Canada), which is an MRS broth devoid of glucose. The medium was supplemented with $0.05 \%(\mathrm{w} / \mathrm{v})$ L-cysteine. $\mathrm{HCl}$ and $0.1 \%(\mathrm{v} / \mathrm{v})$ Tween $80(\mathrm{BDH})$, and one of four sugars was added at $2 \%(\mathrm{w} / \mathrm{v})$ : galactose (MRSCGA2), glucose (MRSCG2), lactose (MRSCL2) or fructose (MRSCF2). Initially, bacteria were transferred from storage at $-80{ }^{\circ} \mathrm{C}$ to each of the four variants of MRS medium containing one of the four sugars and were incubated under anaerobic conditions $\left(10.2 \% \mathrm{CO}_{2}, 10.8 \% \mathrm{H}_{2}\right.$ and $79 \% \mathrm{~N}_{2}$ ) in a Forma 1025 anaerobic chamber (Forma Scientific) for $16 \mathrm{~h}$ at $37^{\circ} \mathrm{C}$. The strain was propagated twice for $8 \mathrm{~h}$ in the same conditions and finally added $(1 \% \mathrm{v} / \mathrm{v})$ to the same four media. Fermentations were monitored for $24 \mathrm{~h}$ and $50 \mathrm{ml}$ samples were removed at regular intervals for $\mathrm{pH}$, titratable acidity, viable counts and RNA extraction. The $\mathrm{pH}$ measurement was carried out with a $\mathrm{pH}$ meter (pHM84; Radiometer) and titratable acidity was determined from $5 \mathrm{ml}$ samples titrated against $0.1 \mathrm{M} \mathrm{NaOH}$ to the phenolphthalein end point ( $\mathrm{pH} \mathrm{8.3)} \mathrm{and} \mathrm{expressed} \mathrm{in} \mathrm{\%} \mathrm{of} \mathrm{equivalent} \mathrm{lactic} \mathrm{acid.}$ Viable counts (c.f.u. $\mathrm{ml}^{-1}$ ) were determined by plating 10 -fold serial dilutions. Four independent fermentations were carried out. ANOVA followed by Tukey-Kramer multiple comparison tests were performed using JMP software (SAS). EPSs were extracted as described above from $10 \mathrm{ml}$ culture samples. The same extraction parameters were applied to the four uninoculated broths, each containing one of the four sugars as controls to correct for contaminating medium components. Total reducing sugar concentration was determined by the phenol/sulfuric method, using glucose as a standard (Dubois et al., 1956).

Detection, cloning and sequencing of genes located in the EPS biosynthesis locus. B. longum subsp. longum CRC 002 genomic DNA was isolated from $1 \mathrm{ml}$ overnight cultures in MRSCG2 medium as described previously (Vincent et al., 1998), with the following modification. The phenol/chloroform/isoamyl alcohol (25:24:1, by vol.) extraction was performed by adding the mixture to a PhaseLock Gel-Heavy tube (Eppendorf). The priming glycosyltransferase (pGTF) was targeted with previously developed hybrid primers G-Bact-a-F-36 and G-Bact-a-R-27 as previously described (Provencher et al., 2003). Genomic DNA from the EPS-producing strain B. longum subsp. longum ATCC 15707 was used as a positive control (Abbad Andaloussi et al., 1995). To isolate genes flanking the pGTF gene from strain CRC 002, probe 1 consisted of the $0.2 \mathrm{~kb}$ DIG-labelled 
PCR fragment (Roche Diagnostics). Hybridizing fragments of the $B$. longum subsp. longum CRC 002 digested genomic DNA (Fig. 1c) were cloned and then sequenced using the genome-walking approach. Primers SLAB38 (5'-CTCGAGACGGAATGCGTTTGTG-3') and SLAB40 (5'-GCGTAAATCGTGGAAGTAA- $\left.3^{\prime}\right)$ were used to create probe 2 in order to detect clones containing the $4.8 \mathrm{~kb} \mathrm{KpnI/EcoRI}$ fragment, which was then sequenced using genome walking (Fig. 1c). All restriction enzymes were purchased from New England Biolabs. Genes $w z b$ and $w z x$ were amplified by PCR using primers listed in Supplementary Table S1 (available with the online version of this paper).

PCR amplification of sugar nucleotide precursor genes. Specific primers (Supplementary Table S1) were designed from two B. longum subsp. longum genomes available from the National Center for Biotechnology Information (NCBI) (strain NCC2705 GenBank accession no. AE014295 and strain DJO10A genome GenBank accession no. CP000605) in order to amplify the galK, galE1, galE2, galT1, galT2, galU, rmlA, rmlB1 and $r m l C D$ genes. PCR was performed with a GeneAmp PCR System 2400 (Perkin-Elmer) according to the following protocol: initial hold for $30 \mathrm{~s}$ at $94{ }^{\circ} \mathrm{C}$, followed by 30 three-step cycles at $94{ }^{\circ} \mathrm{C}$ for $5 \mathrm{~s}, 58{ }^{\circ} \mathrm{C}$ for $30 \mathrm{~s}$ and $72{ }^{\circ} \mathrm{C}$ for $1 \mathrm{~min}$ and a final DNA extension of $5 \mathrm{~min}$ at $72{ }^{\circ} \mathrm{C}$. The PCR products were purified using the QIAquick gel extraction kit (Qiagen), cloned into pCR4-TOPO (Invitrogen) and sequenced as described below.

DNA sequencing and bioinformatics analysis. Recombinant plasmid DNA from selected E. coli TOP10 transformants was purified using the QIAprep Spin Miniprep kit (Qiagen), and inserts were sequenced on both strands using M13 universal primers and custom primers. Sequencing reactions were carried out using the BigDye Terminator V3.1 cycle sequencing kit (Applied Biosystems) as recommended by the manufacturer and were analysed on an (a)

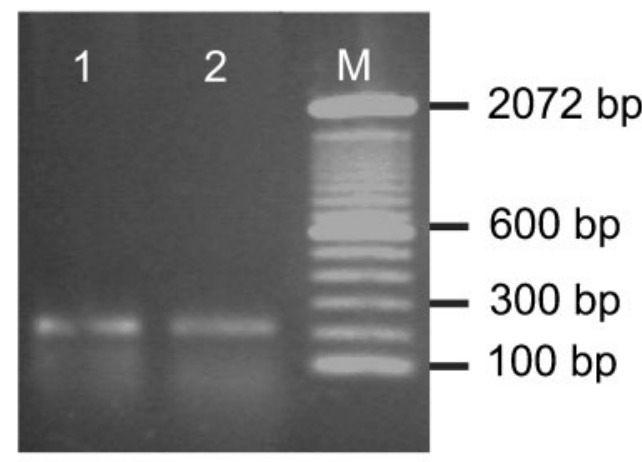

(b)

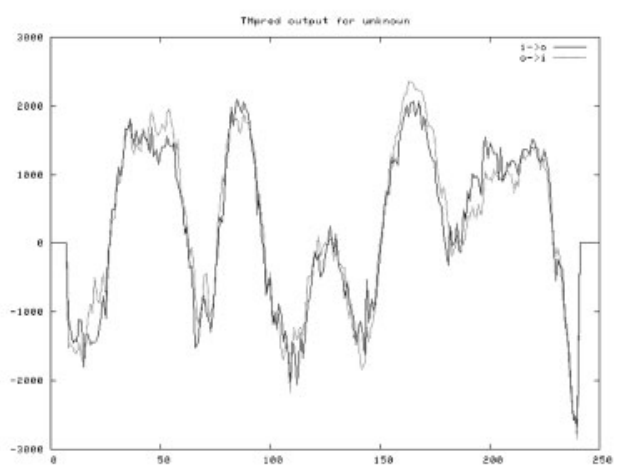

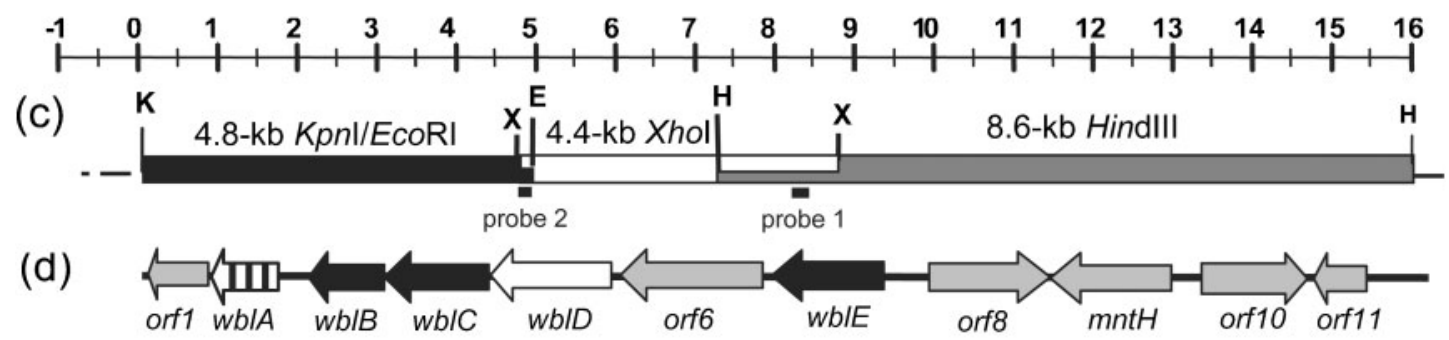

\section{Potential functions: एس Polymerization \\ Glycosyltransferase \\ Chain length \\ determination \\ Not implicated in EPS biosynthesis or unknown function}

Fig. 1. (a) Detection of the potential pGTF gene by PCR using hybrid primers: lane 1, B. longum ATCC $15707^{\top}$ (B. longum subsp. longum type strain producing EPS); lane 2, B. longum subsp. longum CRC 002; M, 100 bp DNA ladder. (b) Hydrophobicity plot of the WbIA putative protein product using the TMpred program. The preferred model predicts that the $\mathrm{N}$ terminus is inside, followed by six strong transmembrane helices. (c) CRC 002 chromosomal DNA restriction map of the putative EPS biosynthesis region. Restriction fragments are designated by numbers indicating the sizes in kb and letters indicating the restriction sites ( $\mathrm{E}$, EcoRl; $\mathrm{H}$, Hindlll; $\mathrm{K}, \mathrm{Kpnl} ; \mathrm{X}, \mathrm{Xhol})$. (d) Predicted ORFs (arrows) from the sequenced region; gene designations are indicated below the arrows. Potential functions are based on homology searches as described in Methods. 
Applied Biosystems 3100 automated DNA sequencer. Nucleotide sequences were assembled and edited with the GCG Wisconsin Package Version 10.3-UNIX (Accelrys). The BLASTX algorithm (http:// www.ncbi.nlm.nih.gov/blast/) was used to perform similarity searches of the nucleotide and protein databases (Altschul et al., 1997). Protein motif similarity searches were carried out with the Pfam database (http://pfam.sanger.ac.uk/) (Finn et al., 2006) and domain architecture similarity searches with CDART (http://www.ncbi.nlm.nih.gov/Structure/ lexington/lexington.cgi/). Sequence alignments were conducted with the CLUSTAL $\mathrm{W}$ server at the European Bioinformatics Institute (http://www.ebi.ac.uk/clustalw/index.html) (Thompson et al., 1994). Sequences were deposited in GenBank under accession numbers EU372989 to EU372994.

RNA extraction. Total RNA from B. longum subsp. longum CRC 002 was extracted at incubation time points $6 \mathrm{~h}, 10 \mathrm{~h}$ and $24 \mathrm{~h}$, which represent the exponential, late-exponential and stationary phases, respectively, in small-scale fermentations. Cell suspensions $(0.5 \mathrm{ml})$ were mixed with RNAprotect Bacteria Reagent (1 ml) (Qiagen). Sample handling and total RNA extraction were performed according to the RNAprotect Bacteria Reagent Handbook with some modifications. The cell pellet was suspended in $\mathrm{T}$ buffer $(10 \mathrm{mM}$ Tris/ $\mathrm{HCl}$ $\mathrm{pH} 8.0)(700 \mu \mathrm{l})$, to which lysozyme $(0.6 \mathrm{mg})$ (Sigma), proteinase $\mathrm{K}$ $(0.4 \mathrm{mg})$ (Sigma) and mutanolysin (200 U) (Sigma) were added, followed by incubation for $10 \mathrm{~min}$ at $37{ }^{\circ} \mathrm{C}$. An RNase-free DNase treatment was carried out directly on the RNeasy column (Qiagen) and a second DNase I ( $5 \mu \mathrm{l}$; Roche Diagnostics) treatment was carried out in the $50 \mu \mathrm{l}$ eluate. DNase was removed with the RNeasy Mini kit clean-up protocol according to the manufacturer's instructions and Protector RNase Inhibitor (160 U) (Roche Diagnostics) was added. The absence of DNA contamination in RNA samples was confirmed by quantitative real-time PCR (Q-PCR) amplification using the tufA primers prior to cDNA synthesis. All RNA samples were visualized on gel and verified for quality by measurement of absorbance at $260 \mathrm{~nm}$ and $280 \mathrm{~nm}$, then quantified with RiboGreen (Invitrogen). RNA $(1 \mu \mathrm{g})$ was reverse transcribed into cDNA in a final volume of $50 \mu \mathrm{l}$ with the High Capacity cDNA Archive kit (Applied Biosystems) as recommended by the manufacturer.

Quantitative real-time reverse transcription PCR (Q-RT-PCR). The primers for Q-RT-PCR were all designed with Primer Express 2.0 (Applied Biosystems) using strain CRC 002-specific sequences for target genes galK, galE1, galE2, galT1, galT2, galU, wblE, rmlA, rmlB1 and $r m l C D$ and reference genes $16 \mathrm{~S}$ rRNA, atpD, ldh, rpoB, tufA and recA (Supplementary Table S1). Melting temperature $\left(T_{\mathrm{m}}\right)$ values were maintained between 58 and $60{ }^{\circ} \mathrm{C}$, while total amplicon size was limited to between 54 and 61 bp with optimized conditions for SYBR Green detection. Primer secondary structures and dimer formation were controlled with Oligo Analyser V3.0 software (http://scitools. idtdna.com). Primers were synthesized by Invitrogen Canada. Q-RTPCR was performed using the ABI PRISM 7500 system (Applied Biosystems). PCR products were detected with SYBR Green fluorescent dye and amplified according to the following protocol: the initial hold for $10 \mathrm{~min}$ at $95{ }^{\circ} \mathrm{C}$ was followed by 40 two-step cycles at $95{ }^{\circ} \mathrm{C}$ for $15 \mathrm{~s}$ and $60{ }^{\circ} \mathrm{C}$ for $60 \mathrm{~s}$. Each PCR contained the following: $12.5 \mu \mathrm{l} 2 \times$ SYBR Green master mix with ROX passive reference dye (Applied Biosystems), $1 \mu \mathrm{l}$ of cDNA dilutions, each of the forward and reverse primers at optimized concentrations (Supplementary Table S2), and nuclease-free water to obtain a final volume of $25 \mu \mathrm{l}$. In each run, negative controls without cDNA for each primer set were included. After each amplification, a melting curve was performed by increasing the temperature by $1{ }^{\circ} \mathrm{C}$ every $20 \mathrm{~s}$ from 65 to $94{ }^{\circ} \mathrm{C}$, to confirm primer specificity. Melting curve analysis showed clear melting peaks without non-specific products or artefacts for all genes.

Relative quantification of gene expression and statistical analysis. Gene transcription was evaluated during the consumption of fructose, galactose or lactose versus the control condition (glucose) using the Relative Expression Software Tool software (REST2005) (Pfaffl et al., 2002). REST2005 considers efficiency (E) for each gene primer set (Peirson et al., 2003) and multiple reference genes to calculate transcription levels (Pfaffl, 2001). Relative expression ratios were established by comparing the concentration for each target gene transcript from treated samples versus control samples, which were then divided by the geometric mean of the most stable reference gene concentration values (Supplementary Table S3) to obtain normalized relative expression levels. The transcription ratio of the 16 genes of interest at $6 \mathrm{~h}, 10 \mathrm{~h}$ and $24 \mathrm{~h}$ in fructose, galactose or lactose versus the control condition (glucose) was tested for significance by randomization and bootstrapping techniques carried out as described by Pfaffl et al. (2002), using 50000 random reallocations.

\section{RESULTS}

\section{Identification and sequence analysis of genes involved in EPS biosynthesis}

The C-terminal domain of the pGTF (priming glycosyltransferase), which catalyses the addition of the first sugar 1-phosphate to a lipophilic carrier molecule for initiation of EPS repeating unit assembly, was amplified from the genomic DNA of B. longum subsp. longum CRC 002 with previously developed hybrid primers (Fig. 1a). The predicted amino acid sequence of the $0.2 \mathrm{~kb}$ PCR product exhibits similarity with the C-terminal region of the $\operatorname{cps} D$ gene from NCC2705, a putative pGTF. By successive hybridizations (Fig. 1c), a $15.9 \mathrm{~kb}$ contiguous sequence was assembled from overlapping fragments (Fig. 1d), giving a $\mathrm{G}+\mathrm{C}$ content of $53.1 \mathrm{~mol} \%$ for the targeted region.

Sequence analysis revealed 11 ORFs (Table 1, Fig. 1d), which are all highly homologous to ORFs found in the genome of B. longum subsp. infantis CCUG 52486 (GenBank accession no. DS990238; Table 1, Fig. 2). Four ORFs (orf8, mntH, orf10 and orf11) showed $99 \%$ amino acid identity with sequences from $B$. longum subsp. longum strains NCC2705 (GenBank accession no. AE014295) and DJO10A (CP000605). Genes wble and wblD share only moderate similarity with sequences from strain NCC2705 while orf6 shares moderate similarity with both NCC2705 and DJO10A (Fig. 2). The wblA gene is predicted to be involved in EPS repeat unit polymerization based on sequence similarity. Analysis of hydrophobicity by TMpred indicates that WblA has six highly probable transmembrane helices (Fig. 1b).

The gene products of $w b l B, w b l C$ and $w b l E$ are predicted to be glycosyltransferases that could be involved in biosynthesis of the repeating unit. No equivalent to the pGTF gene wblE was found in the DJO10A genome (Fig. 2). The predicted WblE protein is classified in the conserved domain database (CDD) within the multi-domain model of EPS biosynthesis polyprenyl glycosylphosphotransferases (TIGR03025). pGTFs from Bifidobacterium spp., Streptococcus thermophilus and pathogenic streptococci as well as enterobacteria include a poorly conserved $\mathrm{N}$ terminus that is not found in equivalent proteins from the 
Table 1. Analysis of ORFs flanking the pGTF gene in B. longum subsp. longum CRC 002

\begin{tabular}{|c|c|c|c|c|c|c|c|c|}
\hline ORF & $\begin{array}{l}\mathrm{Mol} \% \\
\mathrm{G}+\mathrm{C}\end{array}$ & $\begin{array}{l}\text { Amino } \\
\text { acids }\end{array}$ & $\begin{array}{l}\text { Similar } \\
\text { protein }\end{array}$ & $\begin{array}{c}\text { Protein } \\
\text { identity }(\%) / \\
\text { Similarity }(\%)\end{array}$ & $\begin{array}{l}\text { Bacterium with } \\
\text { the most relevant } \\
\text { identity }\end{array}$ & Motif & Potential function & $\begin{array}{l}\text { GenBank/ } \\
\text { UniProtKB/ } \\
\text { TrEMBL }\end{array}$ \\
\hline orf1 & 45 & 307 & BLIG_00241 & 98/99 & $\begin{array}{l}\text { B. longum subsp. infantis } \\
\text { CCUG } 52486\end{array}$ & & Uncharacterized & ZP_03647580 \\
\hline wblA & 36 & 240 & BLIG_00242 & $95 / 97$ & $\begin{array}{l}\text { B. longum subsp. infantis } \\
\text { CCUG } 52486\end{array}$ & Polymerase & Hypothetical protein & ZP_03647581 \\
\hline$w b l B$ & 40 & 315 & BLIG_00243 & $98 / 98$ & $\begin{array}{l}\text { B. longum subsp. infantis } \\
\text { CCUG } 52486\end{array}$ & $\begin{array}{l}\text { pf00535: Glycosyltransferase family 2; } \\
\text { COG0463: Glycosyltransferases involved in } \\
\text { cell wall biogenesis }\end{array}$ & $\beta$-1,4-Galactosyltransferase & ZP_03647582 \\
\hline$w b l C$ & 51 & 378 & BLIG_00244 & $97 / 99$ & $\begin{array}{l}\text { B. longum subsp. infantis } \\
\text { CCUG } 52486\end{array}$ & $\begin{array}{l}\text { pf00534: Glycosyltransferases group 1; } \\
\text { COG0438: Glycosyltransferase }\end{array}$ & Putative glycosyltransferase & ZP_03647583 \\
\hline$w b l D$ & 56 & 492 & BLIG_00245 & $98 / 98$ & $\begin{array}{l}\text { B. longum subsp. infantis } \\
\text { CCUG } 52486\end{array}$ & $\begin{array}{l}\text { pf02706: Chain length determinant protein; } \\
\text { COG3944: Capsular polysaccharide } \\
\text { biosynthesis protein; COG2035: Predicted } \\
\text { membrane protein }\end{array}$ & Etk-like tyrosine kinase & ZP_03647584 \\
\hline orf6 & 57 & 642 & BLIG_00246 & $95 / 97$ & $\begin{array}{l}\text { B. longum subsp. infantis } \\
\text { CCUG } 52486\end{array}$ & & Hypothetical protein & ZP_03647585 \\
\hline$w b l E$ & 56 & 525 & BLIG_00247 & $97 / 98$ & $\begin{array}{l}\text { B. longum subsp. infantis } \\
\text { CCUG } 52486\end{array}$ & $\begin{array}{l}\text { pf02397: Bacterial sugar transferase; } \\
\text { COG2148: Sugar transferases involved in } \\
\text { lipopolysaccharide synthesis }\end{array}$ & pGTF CpsD & ZP_03647586 \\
\hline orf 8 & 61 & 545 & BLIG_00248 & $99 / 100$ & $\begin{array}{l}\text { B. longum subsp. infantis } \\
\text { CCUG } 52486\end{array}$ & $\begin{array}{l}\text { COG0477: Permeases of the major facilitator } \\
\text { superfamily; pf07690: Major Facilitator } \\
\text { Superfamily; COG2814: Arabinose efflux } \\
\text { permease }\end{array}$ & Putative permease & ZP_03647587 \\
\hline$m n t H$ & 61 & 455 & $\mathrm{MntH}$ & $99 / 100$ & B. longum NCC2705 & $\begin{array}{l}\text { pf01566: Natural resistance-associated } \\
\text { macrophage protein; COG1914: } \mathrm{Mn}^{2+} \\
\text { and } \mathrm{Fe}^{2+} \text { transporters of the NRAMP family }\end{array}$ & $\begin{array}{l}\text { NRAMP family } \mathrm{Mn}^{2+} \mathrm{Fe}^{2+} \\
\text { transporter }\end{array}$ & Q8G7L2 \\
\hline orf10 & 50 & 456 & BL0253 & $99 / 100$ & B. longum NCC2705 & $\begin{array}{l}\text { COG1373: Predicted ATPase (AAA+ } \\
\text { superfamily) }\end{array}$ & $\begin{array}{l}\text { Predicted ATPase (AAA+ } \\
\text { superfamily) }\end{array}$ & Q8G7L1 \\
\hline orf11 & 63 & 247 & BL0254 & $99 / 100$ & B. longum NCC2705 & $\begin{array}{l}\text { pf09362: Domain of unknown function } \\
\text { (DUF1996) }\end{array}$ & Uncharacterized protein & Q8G7L0 \\
\hline
\end{tabular}




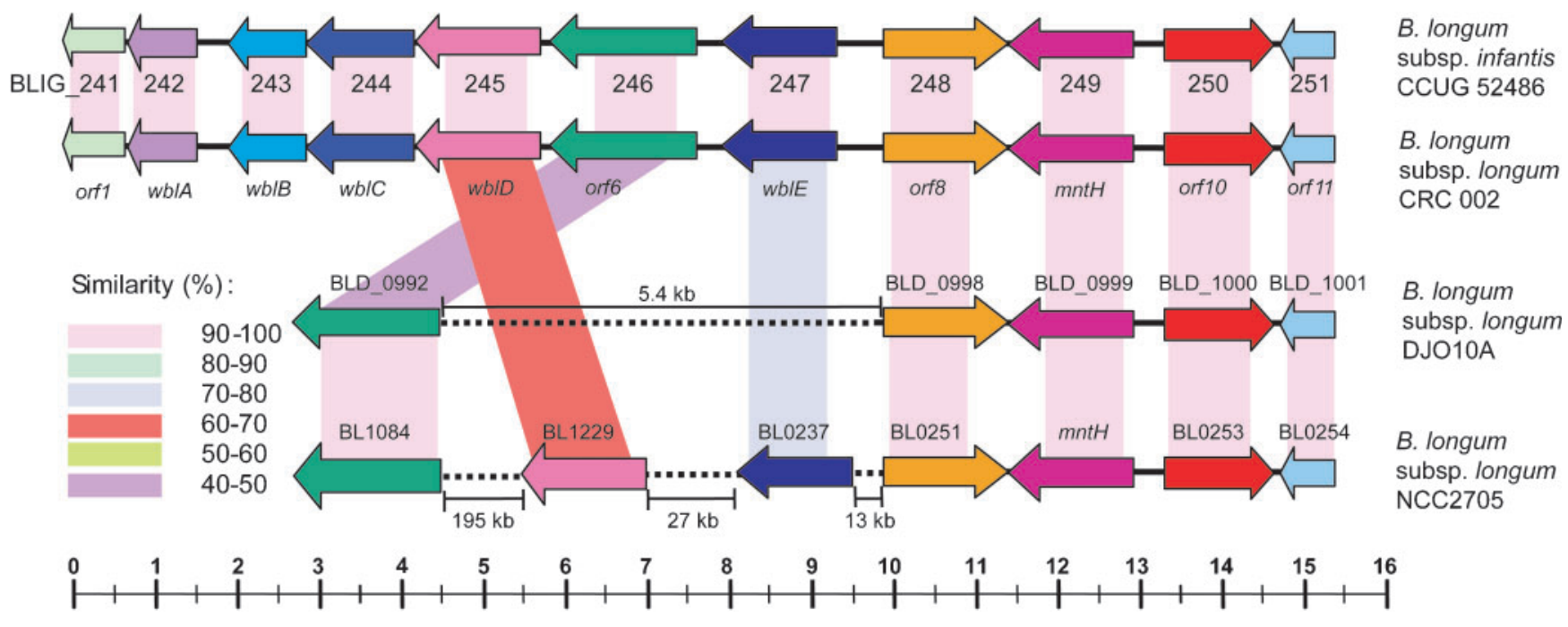

Fig. 2. Comparison of the sequenced region from $B$. longum subsp. longum CRC 002 with $B$. longum subsp. longum NCC 2705 (GenBank accession no. AE014295), B. longum subsp. longum DJO10A (CP000605) and B. longum subsp. infantis CCUG 52486 (DS990238). Arrows with the same colour share the same putative function.

lactobacilli and lactococci. The sequence of WblD has a domain architecture resembling that of the Gram-negative tyrosine kinase involved in the production of group 1 and 4 capsule types (Whitfield, 2006). This protein is expected to potentially be involved in chain length determination. Two further genes were amplified by PCR using primers designed from the highly similar $B$. longum subsp. infantis CCUG 52486 sequences (GenBank accession no. DS990238). Gene $w z x$, located $3 \mathrm{~kb}$ from $w b l A$, encodes a product with the topology of a 'flippase'-type transporter, having 14 transmembrane sequences. Gene $w z b$ is predicted to encode the protein tyrosine phosphatase, completing the functions necessary for chain length determination.

\section{Identification and sequence analysis of genes involved in the biosynthesis of sugar nucleotides as EPS precursors}

The genes and their predicted protein products involved in the biosynthesis of galactose 1-phosphate and glucose 1phosphate and their conversion to EPS precursors (UDPglucose, UDP-galactose and dTDP-rhamnose) were identified from the sequenced $B$. longum subsp. longum NCC2705 and DJO10A genomes (Table 2). Gene organization in B. longum subsp. longum CRC 002 was verified by PCR. The galK gene (galactokinase) is located immediately downstream of galT1 (galactose-1-phosphate uridylyltransferase). The galT2 and galE1 (UDP-glucose 4epimerase) genes are also located together in that order, while galE2 and galU (UTP-glucose-1-phosphate uridylyltransferase) are located separately. The galE2 gene is present in the NCC2705 genome, but no homologous gene was found in the DJO10A genome (Table 2). The $r m l$ genes required for dTDP-rhamnose biosynthesis are organized in a cluster in the order rmlB1-rmlCD-rmlA.

\section{Effect of sugar source on bacterial growth and EPS production}

Galactose, fructose, lactose and glucose were fermented by B. longum subsp. longum CRC 002 with comparable growth profiles (Fig. 3). However, viable plate counts at $24 \mathrm{~h}$ were significantly lower $(P<0.05)$ on fructose versus galactose (Fig. 3). B. longum subsp. longum CRC 002 produced less acid when metabolizing galactose than the other sugars; the final values of $\mathrm{pH}(4.55 \pm 0.02)$ and acidity expressed in \% of equivalent lactic acid $(1.34 \pm 0.08)$ were significantly different $(P<0.05)$. CRC 002 produced significantly more EPS when metabolizing lactose, yielding a total of $1080 \pm 120 \mathrm{mg}$ EPS $\mathrm{l}^{-1}(P<0.01)$ after $24 \mathrm{~h}$ of incubation. For fructose, galactose and glucose, EPS production was

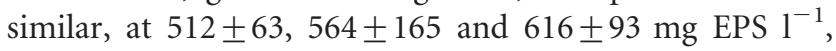
respectively. The monosaccharide composition of EPS from B. longum subsp. longum CRC 002 was $40.0 \pm 1.3 \%$ galactose and $58.5 \pm 2.1 \%$ glucose, giving a proposed repeating unit with a molar ratio of 2 galactose to 3 glucose.

\section{Effect of sugar source on differential gene expression}

Glucose was selected as the control sugar to evaluate differential gene transcription when fructose, lactose and galactose substrates were fermented. The 10 target genes involved in sugar nucleotide biosynthesis and conversion can roughly be divided into three groups: the galK, galT 
Table 2. Genes proposed to be involved in the formation of sugar nucleotides (EPS precursors) by B. longum subsp. longum strain CRC 002 and comparison with homologous genes from B. longum subsp. longum strains NCC2705 and DJO10A

A, Gene absent.

\begin{tabular}{|c|c|c|c|c|c|}
\hline \multirow[t]{2}{*}{ Gene } & \multirow[t]{2}{*}{ Length $(b p)$} & \multirow{2}{*}{$\begin{array}{l}\text { Proposed gene } \\
\text { product }\end{array}$} & \multirow[t]{2}{*}{ Motif } & \multicolumn{2}{|c|}{ DNA identity (\%) } \\
\hline & & & & NCC2705* & $\mathrm{DJO} 10 \mathrm{~A} \dagger$ \\
\hline galE1 & 1022 & UDP-glucose 4-epimerase & $\begin{array}{l}\text { pf01370: NAD dependent epimerase/dehydratase family; } \\
\text { COG1087: UDP-glucose 4-epimerase }\end{array}$ & 95 & 99 \\
\hline galE2 & 1013 & UDP-glucose 4-epimerase & $\begin{array}{l}\text { pf01370: NAD dependent epimerase/dehydratase family; } \\
\text { COG1087: UDP-glucose 4-epimerase }\end{array}$ & 99 & A \\
\hline galK & 1196 & Galactokinase & $\begin{array}{l}\text { pf00288: GHMP kinases N-terminal domain; pf08544: } \\
\text { GHMP kinases C-terminal; COG0153: Galactokinase }\end{array}$ & 97 & 99 \\
\hline galT1 & 1247 & $\begin{array}{l}\text { Galactose-1-phosphate } \\
\text { uridylyltransferase }\end{array}$ & $\begin{array}{l}\text { pf02744: Galactose-1-phosphate uridylyltransferase, C-ter- } \\
\text { minal domain; pf01087: Galactose-1-phosphate uridylyl- } \\
\text { transferase, N-terminal domain; COG1085: Galactose-1- } \\
\text { phosphate uridylyltransferase }\end{array}$ & 93 & 96 \\
\hline galT2 & 1547 & $\begin{array}{l}\text { Galactose-1-phosphate } \\
\text { uridylyltransferase }\end{array}$ & $\begin{array}{l}\text { pf02744: Galactose-1-phosphate uridylyltransferase, C-ter- } \\
\text { minal domain; pf01087: Galactose-1-phosphate uridylyl- } \\
\text { transferase, N-terminal domain; COG1085: Galactose-1- } \\
\text { phosphate uridylyltransferase }\end{array}$ & 96 & 99 \\
\hline galu & 1544 & $\begin{array}{l}\text { UTP-glucose-1-phosphate } \\
\text { uridylyltransferase }\end{array}$ & $\begin{array}{l}\text { pf01704: UTP-glucose-1-phosphate uridylyltransferase; } \\
\text { COG4284: UDP-glucose pyrophosphorylase }\end{array}$ & 97 & 97 \\
\hline rmlA & 862 & $\begin{array}{l}\text { dTDP-glucose } \\
\text { pyrophosphorylase }\end{array}$ & $\begin{array}{l}\text { pf00483: Nucleotidyl transferase; COG1209: dTDP-glucose } \\
\text { pyrophosphorylase }\end{array}$ & 79 & 99 \\
\hline$r m l B 1$ & 1194 & dTDP-glucose 4,6-dehydratase & $\begin{array}{l}\text { pf01370: NAD-dependent epimerase/dehydratase family; } \\
\text { COG1088: dTDP-D-glucose 4,6-dehydratase }\end{array}$ & 74 & 89 \\
\hline$r m l C D$ & 1451 & $\begin{array}{l}\text { Possible fused dTDP-4- } \\
\text { keto-L-rhamnose reductase } \\
\text { and dTDP-4-keto-6- } \\
\text { deoxyglucose 3,5-epimerase }\end{array}$ & $\begin{array}{l}\text { pf00908: dTDP-4-dehydrorhamnose 3,5-epimerase; } \\
\text { pf04321; RmlD substrate-binding domain; COG1898: } \\
\text { dTDP-4-dehydrorhamnose 3,5-epimerase; COG1091: } \\
\text { dTDP-4-dehydrorhamnose reductase }\end{array}$ & 80 & 97 \\
\hline
\end{tabular}

${ }^{\star}$ B. longum subsp. longum NCC2705 (GenBank accession no. AE014295).

$\dagger$ B. longum subsp. longum DJO10A (GenBank accession no. CP000605).

and galE genes from the Leloir pathway, the galU gene involved in UDP-glucose biosynthesis and the rml genes required for dTDP-rhamnose biosynthesis. Transcription levels of the gal genes were influenced by the sugar source, depending on the growth phase (Table 3). Compared to glucose, when galactose was catabolized transcription of the Leloir pathway genes was higher at $6 \mathrm{~h}$. Lactose fermentation led to an increase in transcription for $\mathrm{galK}$, galT1 and galE2. When fructose was fermented, compared to the glucose fermentation, only galE1 transcription was higher. In the late exponential phase $(10 \mathrm{~h})$, the expression of epimerization and galactokinase genes (galE1, galE2 and galK) was influenced by sugars (Table 3 ). Galactose led to increased transcription of the galE2 gene. At $10 \mathrm{~h}$, galK transcription was detected only in galactose $\left(C_{\mathrm{t}}=33.71 \pm 0.95\right)$ and in lactose fermentations $\left(C_{\mathrm{t}}=38.43 \pm 1.35\right)$, not when glucose or fructose were fermented. In the absence of expression in the glucose control condition, no expression ratio could be calculated (absent from Table 3). Even with the overall decline in metabolism through stationary phase $(24 \mathrm{~h})$, differences in transcription of Leloir pathway genes were observed between sugar substrates (Table 3). Galactose fermentation was correlated with higher expression of galT1, galT2 and galE2, but galE1 transcription was comparable to that in glucose fermentation. At $24 \mathrm{~h}$, galK transcription was detected at a very low level only in galactose $\left(C_{\mathrm{t}}=38.20 \pm 1.25\right)$ and in lactose fermentations $\left(C_{\mathrm{t}}=37.79 \pm 0.80\right)$. The galU gene encoding UTP-glucose1-phosphate uridylyltransferase generates UDP-glucose from glucose 1-phosphate, linking glucose metabolism to the Leloir pathway. The galU transcription level was mostly stable among sugar sources for exponential, late-exponential and stationary phases, except for galactose fermentation, where lower transcription was found at $24 \mathrm{~h}$.

In the exponential phase $(6 \mathrm{~h})$, expression of dTDPrhamnose biosynthesis genes $r m l A, r m l B 1$ and $r m l C D$ was significantly higher in fructose and lactose compared to glucose fermentation (Table 3). With galactose, only $r m l C D$ had significantly higher expression than in glucose at $6 \mathrm{~h}$. At later growth stages, $r m l A$ transcription did not vary significantly compared to glucose. No transcription of rmlB1 was detected in stationary phase for any of the sugar 
(a) Glucose

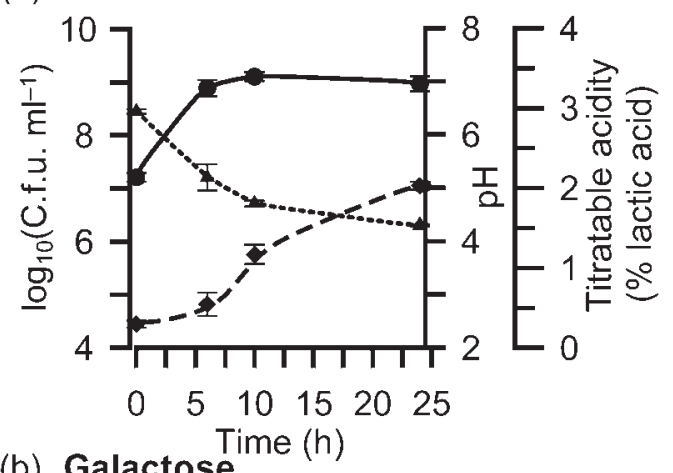

(b) Galactose

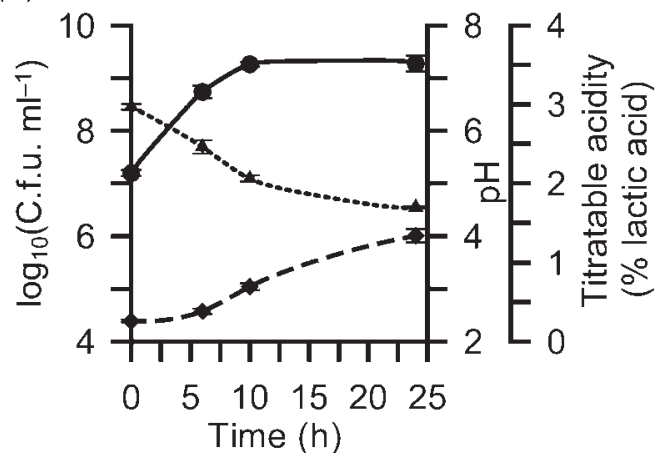

(c) Fructose

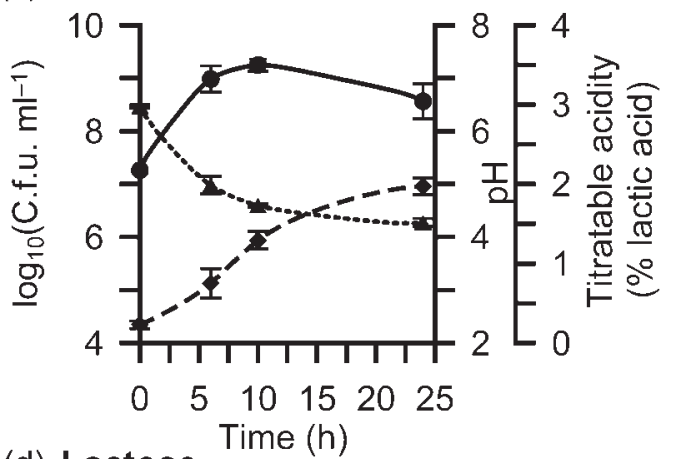

(d) Lactose

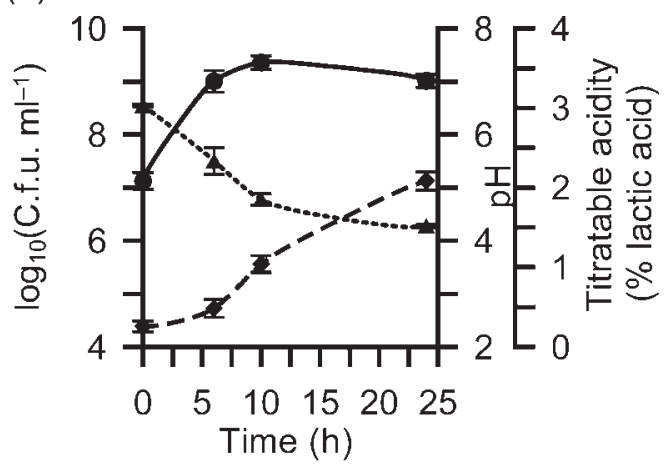

Fig. 3. Growth profiles of $B$. longum subsp. longum CRC 002 in MRSCG2 (a), MRSCGA2 (b), MRSCF2 (c) and MRSCL2 (d) at $37{ }^{\circ} \mathrm{C}$. Viable cell count $(\bullet$, solid lines), $\mathrm{pH}(\boldsymbol{\Delta}$; dotted lines) and titratable acidity in \% of equivalent lactic acid ( $\boldsymbol{\nabla}$; dashed lines). Error bars: standard error of four independent experiments. sources. In stationary phase, $r m l C D$ gene expression was significantly lower in lactose and galactose compared to glucose.

Transcription of the wblE gene in the exponential phase $(6 \mathrm{~h})$ was higher in fructose and lactose fermentations, compared to glucose fermentation (Table 3). In contrast, at $10 \mathrm{~h}$, wblE transcription was lower for all sugars compared to glucose and no transcription was detected for any of the sugar substrates at $24 \mathrm{~h}$ (Table 3 ).

\section{DISCUSSION}

The EPS-producing bifidobacteria may influence the rheological behaviour of fermented food products, but they may also affect bacterial adhesion properties of some indigenous members of the human microbiota when products are ingested (Ruas-Madiedo et al., 2006). The human intestinal ecosystem has been screened for EPS + strains, and EPS + bifidobacteria found were B. pseudocatenulatum, B. longum, B. animalis and B. adolescentis (Ruas-Madiedo et al., 2007). However, little is known about EPS biosynthesis by Bifidobacterium spp., and no information about eps operons was available prior to this study. This study presents a potentially new EPS isolated from B. longum subsp. longum CRC 002 with a proposed repeating unit composition of 2 galactose: 3 glucose, which is different from other excreted EPS characterized from $B$. longum (Abbad Andaloussi et al., 1995; Roberts et al., 1995; Salazar et al., 2009) as well as from B. pseudocatenulatum (Salazar et al., 2009). The EPS composition among B. longum subsp. longum strains seems diverse, which agrees with the strain variation found within other genera such as Streptococcus, Lactococcus and Lactobacillus (Broadbent et al., 2003; De Vuyst \& Degeest, 1999; Marshall et al., 2001). Although strain CRC 002 might produce multiple EPS polymers, the extraction procedure recovers all EPS present in the culture supernatant, and the compositional analysis did not show the presence of rhamnose. This result points towards a secreted heteropolysaccharide; further studies are needed to determine the structure of the repeat unit. Although not present in the EPS, the rhamnose precursor may be used in cell wall polysaccharide biosynthesis, shunting glucose away from glycolysis and from production of other EPS precursor sugars.

The presence of genes encoding specific glycosyltransferases has a direct impact on the repeating units of the polymers, and monomer composition diversity may suggest different EPS-specific genes for B. longum subsp. longum strains (Jolly \& Stingele, 2001; van Kranenburg et al., 1999). Potential genes were identified from the CRC 002 strain in order to correlate gene expression with EPS production. The hybrid primers used to detect the pGTF were originally applied to Lactobacillus and Streptococcus species by our group (Provencher et al., 2003). As the pGTF was successfully amplified from $B$. longum subsp. longum CRC 002 and ATCC 15707, this indicates that 
Table 3. Relative transcription ratios of $10 \mathrm{~B}$. longum subsp. longum CRC 002 genes when fructose, lactose or galactose were fermented versus the control fermentation with glucose in MRS broth

Transcription ratios were calculated using the relative expression software tool (REST2005). The values shown are means ( $n=4)$, where probability was calculated by the pair-wise fixed reallocation randomization test (50000 permutations) between samples and control groups $\left({ }^{\star} P<0.05\right.$; $\dagger P<0.01 ; \ddagger P<0.001)$. The geometric means of control genes within each time point were used to normalize the Q-RT-PCR data as described in the supplementary material. ND, Not detected.

\begin{tabular}{|c|c|c|c|c|c|c|c|c|c|}
\hline \multirow[t]{2}{*}{ Gene } & \multicolumn{3}{|c|}{ Fructose } & \multicolumn{3}{|c|}{ Lactose } & \multicolumn{3}{|c|}{ Galactose } \\
\hline & $6 \mathrm{~h}$ & $10 \mathrm{~h}$ & $24 \mathrm{~h}$ & $6 \mathrm{~h}$ & $10 \mathrm{~h}$ & $24 \mathrm{~h}$ & $6 \mathrm{~h}$ & $10 \mathrm{~h}$ & $24 \mathrm{~h}$ \\
\hline galE2 & 1.76 & $0.33^{*}$ & 1.18 & $4.95 \ddagger$ & 1.50 & 0.78 & $11.33 \ddagger$ & $14.91 \dagger$ & $3.81 \dagger$ \\
\hline galK & 1.27 & $\mathrm{ND}$ & $\mathrm{ND}$ & $4.10 \ddagger$ & $\mathrm{ND}$ & $\mathrm{ND}$ & $6.29 \ddagger$ & ND & ND \\
\hline galT1 & 1.44 & 1.65 & $2.00^{*}$ & $2.78^{*}$ & 0.52 & $2.03^{*}$ & $4.44^{*}$ & 2.17 & $2.43 \dagger$ \\
\hline rmlA & $3.96 \ddagger$ & 0.53 & 0.81 & $6.72 \ddagger$ & 0.55 & 1.65 & $2.63 \ddagger$ & 1.33 & 0.80 \\
\hline rmlB1 & $2.39^{*}$ & 0.86 & $\mathrm{ND}$ & 1.37 & 0.56 & $\mathrm{ND}$ & 1.31 & $0.28^{*}$ & ND \\
\hline $\mathrm{rmlCD}$ & $5.76 \neq$ & $2.54 \dagger$ & 1.47 & $0.34^{*}$ & 3.32 & $0.26^{*}$ & $5.12 \dagger$ & 0.61 & 0.03 末 \\
\hline wble & $6.14 \ddagger$ & $0.09 \neq$ & $\mathrm{ND}$ & $9.29 \neq$ & $0.10 \ddagger$ & ND & 1.61 & $0.02 \ddagger$ & ND \\
\hline
\end{tabular}

primers designed using CODEHOP with A+T-rich genomes can be applied to new genera with very different mol\% G $+\mathrm{C}$ content. Although these primers detect a pGTF gene in specific strains, not all EPS-producing strains may have the same type of gene. In fact, these primers detected a similar gene in only $7 \%$ of lactobacilli and bifidobacteria strains tested originating from human gastrointestinal microbiota (Ruas-Madiedo et al., 2007). Diversity in EPS biosynthetic mechanisms and sequences among bifidobacteria would account for this.

All the functions necessary for heteropolysaccharide biosynthesis were found flanking the pGTF. Seven predicted gene products could potentially be involved in EPS production, with putative biological functions covering biosynthesis of the repeating unit (WblB, WblC and $\mathrm{WblE}$ ), transport (Wzx), polymerization (WblA) and chain length determination (WblD, Wzb). The EPS biosynthesis region from CRC 002 contains four genes ( $w b l A, w b l B$, $w b l C$ and $w z x$ ) with no homologues in two sequenced $B$. longum subsp. longum genomes (Schell et al., 2002), but present in the genome sequence of B. longum subsp. infantis CCUG 52486. In this respect, recent comparison of the CRC 002 genome with that of NCC2705 by suppressive subtractive hybridization ( $\mathrm{SSH}$ ) revealed five glycosyltransferase genes in the CRC 002 strain that were not found in NCC2705 (Delcenserie et al., 2008). One of these is identical to $w b l C$ identified in the present study, while $w b l A$ was also identified by SSH in the previous study.

The quantity of EPS produced by strain CRC 002 differed between sugar substrates. Even without pH control, EPS production exceeded $1 \mathrm{~g} \mathrm{l}^{-1}$ in lactose fermentations. This strain shows high productivity compared to other bifidobacteria and many, if not most, lactic acid bacteria that produce heteropolymers (Cerning, 1995). This may be related to the higher ATP production made possible by acetate production through the bifidus shunt (Palframan et al., 2003). Although cell growth was not significantly higher, lactose seems to be the better sugar source for strain CRC 002 to produce EPS, as found previously for strain BB-79 (Roberts et al., 1995). Lactose is preferred over glucose by B. longum subsp. longum NCC2705, as suggested by transcriptional repression of $g l p P$, a glucose uptake gene (Parche et al., 2007). As a disaccharide, lactose provides glucose for glycolysis as well as galactose that can be shunted directly to the Leloir pathway for sugar nucleotide biosynthesis. In addition, there are at least three permease systems in B. longum subsp. longum NCC2705 that are active for lactose uptake, while glucose is transported by two systems, of which the phosphotransferase is transcribed at a low level (Parche et al., 2007). In order to determine whether the differences in EPS production between cultures of B. longum subsp. longum CRC 002 grown on different sugars could be correlated with the expression of genes involved in glycosyltransferase activity or precursor biosynthesis, differential gene transcription was investigated by Q-RT-PCR.

In Lactobacillus delbrueckii subsp. bulgaricus, higher EPS production was associated with higher levels of UDPglucose pyrophosphorylase (GalU) and UDP-glucose epimerase (GalE) enzyme activities at higher growth rates (Welman et al., 2006). In the present study, the transcription level of galU was not correlated with changes in EPS production in B. longum subsp. longum strain CRC 002, so glucose may not contribute to increasing the UDPglucose precursor pool for EPS production. Genes of the Leloir pathway (galK, galE1, galE2, galT1 and galT2), however, were induced by galactose and lactose during exponential growth, which contributes directly to increasing UDP-galactose and then to UDP-glucose formation, 
thus increasing the pool of precursors for EPS production. Interestingly, the GalE and GalT enzymes are each encoded by two different genes, and sugar source does not appear to have the same effect on their transcription. This suggests different transcriptional regulation mechanisms for these duplicate genes encoding the same function. Moreover, even though rhamnose was not present in the EPS produced by B. longum subsp. longum CRC 002, dTDPrhamnose may be needed as a sugar precursor in cell wall polysaccharide biosynthesis (Nagaoka et al., 1995), and shunt glucose away from glycolysis. In fact, $\mathrm{rml}$ genes were differentially expressed depending on the sugar source and growth phase.

To increase EPS production, metabolic engineering has been attempted to overcome regulation in the basal metabolic reactions involved in sugar nucleotide biosynthesis in Lactococcus lactis and Streptococcus thermophilus (Boels et al., 2001a, 2003a; Levander \& Rådström, 2001; Levander et al., 2002; Looijesteijn et al., 1999). EPS yields have been enhanced in $S$. thermophilus by overexpressing genes coding for the Leloir enzymes (Levander et al., 2002; Svensson et al., 2005). EPS biosynthesis pathways and regulation mechanisms are generally complex, and enhancement of EPS production when metabolizing lactose may not be explained only by sugar nucleotide biosynthesis. Hypothetically, the galactose moiety from lactose hydrolysis, which induced gene transcription of the Leloir pathway, can be seen as a bypass from the stable noninducible galU gene. In L. lactis, EPS production increased fourfold when the eps gene cluster was overexpressed by cloning into a high-copy-number vector (Boels et al., 2003b). The overexpression of EPS-specific genes in $B$. longum subsp. longum CRC 002 also seems to have an important impact. In fact, the transcription of the CRC 002 wblE pGTF was upregulated almost 10-fold in lactose over glucose in the exponential phase. Thus, the pGTF gene wblE can be used as an indicator of EPS gene expression.

In summary, this study reports the identification, sequence and expression of genes predicted to be involved in sugar nucleotide production and EPS biosynthesis by B. longum subsp. longum CRC 002. We demonstrate the impact of sugar source on gene expression as a measure of metabolic activity. Thus, genes located in multiple transcriptional units were targeted, focusing on the pGTF as well as sugar nucleotide precursors for glucose, galactose and rhamnose. B. longum subsp. longum CRC 002 produces a high level of a potentially novel EPS consisting of glucose and galactose. Compared to glucose fermentations, when this strain catabolizes lactose, higher EPS production is associated with higher expression of the wblE gene and sugar nucleotide genes in the exponential phase, emphasizing the pertinence of targeting the pGTF as a key enzyme in the biosynthetic mechanism.

\section{ACKNOWLEDGEMENTS}

This work was funded by the Natural Sciences and Engineering Research Council of Canada (G.L.) and by the Government of
Canada (via a Canada Research Chair in Lactic Culture Biotechnology for Dairy and Probiotic Industries held by D. R.). The authors wish to thank Pierre Ward for the EPS monomer determination by GLC and Marie Filteau for technical help.

\section{REFERENCES}

Abbad Andaloussi, S., Talbaoui, H., Marczak, R. \& Bonaly, R. (1995). Isolation and characterization of exocellular polysaccharides produced by Bifidobacterium longum. Appl Microbiol Biotechnol 43, 9951000.

Altschul, S. F., Madden, T. L., Schäffer, A. A., Zhang, J., Zhang, Z., Miller, W. \& Lipman, D. J. (1997). Gapped BLAST and PSI-BLAST: a new generation of protein database search programs. Nucleic Acids Res 25, 3389-3402.

Boels, I. C., Ramos, A., Kleerebezem, M. \& de Vos, W. M. (2001a). Functional analysis of the Lactococcus lactis galU and galE genes and their impact on sugar nucleotide and exopolysaccharide biosynthesis. Appl Environ Microbiol 67, 3033-3040.

Boels, I. C., van Kranenburg, R., Hugenholtz, J., Kleerebezem, M. \& de Vos, W. M. (2001b). Sugar catabolism and its impact on the biosynthesis and engineering of exopolysaccharide production in lactic acid bacteria. Int Dairy J 11, 723-732.

Boels, I. C., Kleerebezem, M. \& de Vos, W. M. (2003a). Engineering of carbon distribution between glycolysis and sugar nucleotide biosynthesis in Lactococcus lactis. Appl Environ Microbiol 69, 11291135.

Boels, I. C., van Kranenburg, R., Kanning, M. W., Chong, B. F., de Vos, W. M. \& Kleerebezem, M. (2003b). Increased exopolysaccharide production in Lactococcus lactis due to increased levels of expression of the NIZO B40 eps gene cluster. Appl Environ Microbiol 69, 50295031.

Broadbent, J. R., McMahon, D. J., Welker, D. L., Oberg, C. J. \& Moineau, S. (2003). Biochemistry, genetics, and applications of exopolysaccharide production in Streptococcus thermophilus: a review. J Dairy Sci 86, 407-423.

Cerning, J. (1995). Production of exopolysaccharides by lactic acid bacteria and dairy propionibacteria. Lait 75, 463-472.

Cerning, J., Renard, C. M. G. C., Thibault, J. F., Bouillanne, C., Landon, M., Desmazeaud, M. \& Topisirovic, L. (1994). Carbon source requirements for exopolysaccharide production by Lactobacillus casei CG11 and partial structure analysis of the polymer. Appl Environ Microbiol 60, 3914-3919.

Dabour, N. \& LaPointe, G. (2005). Identification and molecular characterization of the chromosomal exopolysaccharide biosynthesis gene cluster from Lactococcus lactis subsp. cremoris SMQ-461. Appl Environ Microbiol 71, 7414-7425.

Degeest, B. \& De Vuyst, L. (1999). Indication that the nitrogen source influences both amount and size of exopolysaccharides produced by Streptococcus thermophilus LY03 and modelling of the bacterial growth and exopolysaccharide production in a complex medium. Appl Environ Microbiol 65, 2863-2870.

Degeest, B. \& De Vuyst, L. (2000). Correlation of activities of the enzymes alpha-phosphoglucomutase, UDP-galactose 4-epimerase, and UDP-glucose pyrophosphorylase with exopolysaccharide biosynthesis by Streptococcus thermophilus LY03. Appl Environ Microbiol 66, 3519-3527.

Degeest, B., Vaningelgem, F. \& De Vuyst, L. (2001). Microbial physiology, fermentation kinetics, and process engineering of heteropolysaccharide production by lactic acid bacteria. Int Dairy J 11, 747-757. 
Delcenserie, V., Lessard, M. H., LaPointe, G. \& Roy, D. (2008). Genome comparison of Bifidobacterium longum strains NCC2705 and CRC-002 using suppression subtractive hybridization. FEMS Microbiol Lett 280, 50-56.

De Vuyst, L. \& Degeest, B. (1999). Heteropolysaccharides from lactic acid bacteria. FEMS Microbiol Rev 23, 153-177.

De Vuyst, L., De Vin, F., Vaningelgem, F. \& Degeest, B. (2001). Recent developments in the biosynthesis and applications of heteropolysaccharides from lactic acid bacteria. Int Dairy J 11, 687-707.

Dubois, M., Gilles, K. A., Hamilton, J. K., Rebers, P. A. \& Smith, F. (1956). Colorimetric method for determination of sugars and related substances. Anal Chem 28, 350-356.

Finn, R. D., Mistry, J., Schuster-Böckler, B., Griffiths-Jones, S., Hollich, V., Lassmann, T., Moxon, S., Marshall, M., Khanna, A. \& other authors (2006). Pfam: clans, web tools and services. Nucleic Acids Res 34, D247-D251.

Grand, M., Küffer, M. \& Baumgartner, A. (2003). Quantitative analysis and molecular identification of bifidobacteria strains in probiotic milk products. Eur Food Res Technol 217, 90-92.

Hsieh, Y. C., Liang, S. M., Tsai, W. L., Chen, Y. H., Liu, T. Y. \& Liang, C. M. (2003). Study of capsular polysaccharide from Vibrio parahaemolyticus. Infect Immun 71, 3329-3336.

Hung, D. T., Zhu, J., Sturtevant, D. \& Mekalanos, J. J. (2006). Bile acids stimulate biofilm formation in Vibrio cholerae. Mol Microbiol 59, 193-201.

Jolly, L. \& Stingele, F. (2001). Molecular organization and functionality of exopolysaccharide gene clusters in lactic acid bacteria. Int Dairy J 11, 733-745.

Kohno, M., Suzuki, S., Kanaya, T., Yoshino, T., Matsuura, Y., Asada, M. \& Kitamura, S. (2009). Structural characterization of the extracellular polysaccharide produced by Bifidobacterium longum JBL05. Carbohydr Polym 77, 351-357.

Laws, A. P. \& Marshall, V. M. (2001). The relevance of exopolysaccharides to the rheological properties in milk fermented with ropy strains of lactic acid bacteria. Int Dairy J 11, 709-721.

Leahy, S. C., Higgins, D. G., Fitzgerald, G. F. \& van Sinderen, D. (2005). Getting better with bifidobacteria. J Appl Microbiol 98, 13031315.

Levander, F. \& Rådström, P. (2001). Requirement for phosphoglucomutase in exopolysaccharide biosynthesis in glucose- and lactoseutilizing Streptococcus thermophilus. Appl Environ Microbiol 67, 2734 2738.

Levander, F., Svensson, M. \& Rådström, P. (2002). Enhanced exopolysaccharide production by metabolic engineering of Streptococcus thermophilus. Appl Environ Microbiol 68, 784-790.

Looijesteijn, P. J., Boels, I. C., Kleerebezem, M. \& Hugenholtz, J. (1999). Regulation of exopolysaccharide production by Lactococcus lactis subsp. cremoris by the sugar source. Appl Environ Microbiol 65 , 5003-5008.

Marshall, V. M., Laws, A. P., Gu, Y., Levander, F., Rådström, P., De Vuyst, L., Degeest, B., Vaningelgem, F., Dunn, H. \& other authors (2001). Exopolysaccharide-producing strains of thermophilic lactic acid bacteria cluster into groups according to their EPS structure. Lett Appl Microbiol 32, 433-437.

Masco, L., Vanhoutte, T., Temmerman, R., Swings, J. \& Huys, G. (2007). Evaluation of real-time PCR targeting the $16 \mathrm{~S}$ rRNA and recA genes for the enumeration of bifidobacteria in probiotic products. Int J Food Microbiol 113, 351-357.

Mazmanian, S. K. \& Kasper, D. L. (2006). The love-hate relationship between bacterial polysaccharides and the host immune system. Nat Rev Immunol 6, 849-858.
Nagaoka, M., Shibata, H., Kimura, I., Hashimoto, S., Kimura, K., Sawada, H. \& Yokokura, T. (1995). Structural studies on a cell wall polysaccharide from Bifidobacterium longum YIT4028. Carbohydr Res 274, 245-249.

Norris, R. F., Flanders, T., Tomarelli, R. M. \& György, P. (1950). The isolation and cultivation of Lactobacillus bifidus; a comparison of branched and unbranched strains. J Bacteriol 60, 681-696.

Palframan, R. J., Gibson, G. R. \& Rastall, R. A. (2003). Carbohydrate preferences of Bifidobacterium species isolated from the human gut. Curr Issues Intest Microbiol 4, 71-75.

Parche, S., Beleut, M., Rezzonico, E., Jacobs, D., Arigoni, F., Titgemeyer, F. \& Jankovic, I. (2006). Lactose-over-glucose preference in Bifidobacterium longum NCC2705: glcP, encoding a glucose transporter, is subject to lactose repression. J Bacteriol 188, 1260-1265.

Parche, S., Amon, J., Jankovic, I., Rezzonico, E., Beleut, M., Barutçu, H., Schendel, I., Eddy, M. P., Burkovski, A. \& other authors (2007). Sugar transport systems of Bifidobacterium longum NCC2705. J Mol Microbiol Biotechnol 12, 9-19.

Peirson, S. N., Butler, J. N. \& Foster, R. G. (2003). Experimental validation of novel and conventional approaches to quantitative realtime PCR data analysis. Nucleic Acids Res 31, e73.

Pfaffl, M. W. (2001). A new mathematical model for relative quantification in real-time RT-PCR. Nucleic Acids Res 29, e45.

Pfaffl, M. W., Horgan, G. W. \& Dempfle, L. (2002). Relative expression software tool (REST) for group-wise comparison and statistical analysis of relative expression results in real-time PCR. Nucleic Acids Res 30, e36.

Picard, C., Fioramonti, J., Francois, A., Robinson, T., Neant, F. \& Matuchansky, C. (2005). Review article: bifidobacteria as probiotic agents - physiological effects and clinical benefits. Aliment Pharmacol Ther 22, 495-512.

Poupard, J. A., Husain, I. \& Norris, R. F. (1973). Biology of the bifidobacteria. Bacteriol Rev 37, 136-165.

Provencher, C., LaPointe, G., Sirois, S., Van Calsteren, M. R. \& Roy, D. (2003). Consensus-degenerate hybrid oligonucleotide primers for amplification of priming glycosyltransferase genes of the exopolysaccharide locus in strains of the Lactobacillus casei group. Appl Environ Microbiol 69, 3299-3307.

Roberts, C. M., Fett, W. F., Osman, S. F., Wijey, C., O'Connor, J. V. \& Hoover, D. G. (1995). Exopolysaccharide production by Bifidobacterium longum BB-79. J Appl Bacteriol 78, 463-468.

Roy, D. (2005). Technological aspects related to the use of bifidobacteria in dairy products. Lait 85, 39-56.

Roy, D., Chevalier, P., Ward, P. \& Savoie, L. (1991). Sugars fermented by Bifidobacterium infantis ATCC 27920 in relation to growth and $\alpha$ galactosidase activity. Appl Microbiol Biotechnol 34, 653-655.

Ruas-Madiedo, P. \& de los Reyes-Gavilán, C. G. (2005). Invited review: methods for the screening, isolation, and characterization of exopolysaccharides produced by lactic acid bacteria. J Dairy Sci 88, 843-856.

Ruas-Madiedo, P., Gueimonde, M., Margolles, A., de los ReyesGavilán, C. G. \& Salminen, S. (2006). Exopolysaccharides produced by probiotic strains modify the adhesion of probiotics and enteropathogens to human intestinal mucus. J Food Prot 69, 2011-2015.

Ruas-Madiedo, P., Moreno, J. A., Salazar, N., Delgado, S., Mayo, B., Margolles, A. \& de los Reyes-Gavilán, C. G. (2007). Screening of exopolysaccharide-producing Lactobacillus and Bifidobacterium strains isolated from the human intestinal microbiota. Appl Environ Microbiol 73, 4385-4388.

Ruas-Madiedo, P., Gueimonde, M., Arigoni, F., de los ReyesGavilán, C. G. \& Margolles, A. (2009). Bile affects the synthesis of 
exopolysaccharides by Bifidobacterium animalis. Appl Environ Microbiol 75, 1204-1207.

Salazar, N., Gueimonde, M., Hernandez-Barranco, A. M., RuasMadiedo, P. \& de los Reyes-Gavilán, C. G. (2008). Exopolysaccharides produced by intestinal Bifidobacterium strains act as fermentable substrates for human intestinal bacteria. Appl Environ Microbiol 74, 4737-4745.

Salazar, N., Prieto, A., Leal, J. A., Mayo, B., Bada-Gancedo, J. C., de los Reyes-Gavilán, C. G. \& Ruas-Madiedo, P. (2009). Production of exopolysaccharides by Lactobacillus and Bifidobacterium strains of human origin, and metabolic activity of the producing bacteria in milk. J Dairy Sci 92, 4158-4168.

Schell, M. A., Karmirantzou, M., Snel, B., Vilanova, D., Berger, B., Pessi, G., Zwahlen, M. C., Desiere, F., Bork, P. \& other authors (2002). The genome sequence of Bifidobacterium longum reflects its adaptation to the human gastrointestinal tract. Proc Natl Acad Sci U S A 99, 14422-14427.

Stanton, C., Gardiner, G., Lynch, P. B., Collins, J. K., Fitzgerald, G. \& Ross, R. P. (1998). Probiotic cheese. Int Dairy J 8, 491-496.

Svensson, M., Waak, E., Svensson, U. \& Rådström, P. (2005). Metabolically improved exopolysaccharide production by Streptococcus thermophilus and its influence on the rheological properties of fermented milk. Appl Environ Microbiol 71, 6398-6400.
Thompson, J. D., Higgins, D. G. \& Gibson, T. J. (1994). CLUSTAL W: improving the sensitivity of progressive multiple sequence alignment through sequence weighting, position-specific gap penalties and weight matrix choice. Nucleic Acids Res 22, 4673-4680.

Van Calsteren, M. R., Pau-Roblot, C., Bégin, A. \& Roy, D. (2002). Structure determination of the exopolysaccharide produced by Lactobacillus rhamnosus strains RW-9595M and R. Biochem J 363, 7-17.

van Kranenburg, R., Boels, I. C., Kleerebezem, M. \& de Vos, W. M. (1999). Genetics and engineering of microbial exopolysaccharides for food: approaches for the production of existing and novel polysaccharides. Curr Opin Biotechnol 10, 498-504.

Vincent, D., Roy, D., Mondou, F. \& Déry, C. (1998). Characterization of bifidobacteria by random DNA amplification. Int J Food Microbiol 43, 185-193.

Welman, A. D., Maddox, I. S. \& Archer, R. H. (2006). Metabolism associated with raised metabolic flux to sugar nucleotide precursors of exopolysaccharides in Lactobacillus delbrueckii subsp. bulgaricus. J Ind Microbiol Biotechnol 33, 391-400.

Whitfield, C. (2006). Biosynthesis and assembly of capsular polysaccharides in Escherichia coli. Annu Rev Biochem 75, 39-68.

Edited by: H. J. Flint 